\title{
The Role of Folate Dependent Genetic Susceptibility in The Risk of Multiple Sclerosis
}

\section{Ali Erkan Asci and Bensu Karahalil}

Department of Toxicology, Faculty of Pharmacy, Gazi University, 06330 Ankara, Turkey

Corresponding author: Prof. Dr. Bensu Karahalil, Department of Toxicology, Faculty of Pharmacy, Gazi University, 06330 Ankara, Turkey, Tel: +90 312 2023082; Fax: +90 31222223 26; E-mail: bensuka@gmail.com

Received: Apr 02, 2017; Accepted: Apr 28, 2017; Published: May 02, 2017

Citation: Erkan-Asci A, Karahalil B. The Role of Folate Dependent Genetic Susceptibility in The Risk of Multiple Sclerosis. J Neurol Neurosci 2017, 8: 3.

\section{Abstract}

Background: Multiple sclerosis (MS) is a chronic inflammatory disease of the central nervous system (CNS) of unknown cause. Epidemiological studies implicate that genetic and environmental factors interplay major roles in the etiology of MS. Several investigators have reported elevated plasma homocysteine and reduced folate and B vitamin levels in MS. Aberrations in one-carbon metabolism have impact in the pathophysiology by genetic susceptibility and increased the risk of MS. Furthermore, abnormalities in a carbon metabolism pathway may result from environmental factors such as reduced levels of vitamin $B$ and folate due to inadequate $B$ vitamin and folate intake from foods or the problems on their synthesis, and genetic factors such as polymorphism in folate-dependent enzymes.

Results: Many studies showed conflictive results genetic polymorphisms on the risk of MS. In the present review, we have emphasized the genetic susceptibility to the risk of MS, especially genetic polymorphisms on one carbon metabolism pathway. The associations on individual differences on the levels of homocysteine, B vitamin, folic acid due to genetic make-up and the risk of MS will be discussed. There are numerous reasons causing the development of MS especially, individual susceptibility should not be neglected. We have focused on three gene polymorphisms namely Methylene tetrahydrofolate reductase (MTHFR) C677T, A1298C and Methionine synthase (MTR) G66A since they are key enzymes on one carbon metabolism pathway.

Conclusion: So far conducted studies showed that genetic factors on products of one carbon pathway have major roles and these factors contribute to the development of MS. Individual differences in the development and treatment of the disease should not be overlooked.

Keywords: Multiple sclerosis; Homocysteine; Methylenetetrahydrofolate Reductase (MTHFR);
Methionine Synthase Reductase (MTRR); Methionine Synthase (MTR)

\section{Introduction}

Multiple sclerosis (MS) is characterized by inflammation, demyelination and axon damage. It is an autoimmune central nervous system (CNS) disease. Myelin sheaths, oligodendrocytes the axon and nerve cells are damaged. The disease often occurs in young adults. The prevalence is ranges from 2 to 200 per 100000 depending on geographical features. It was first reported by Jean-Martin Charcot in 1868 that MS was a chronic disease [1]. MS generally starts during the most productive period of life. It leads the significant disabilities and labor loss, thus affects quality of life. Furthermore, high treatment costs cause this disease to be discussed at the social dimension as much as individual [2]. In $\mathrm{MS}$, inflammatory plaques in the brain and spinal cord cause multiple attacks of multifocal neurological deficits, with attacks of illness and recurrent episodes of recovery. The plaques are characteristically numerous and vary with age. Each attack which becomes permanent causes the loss of axon and leads to progressive loss of neurological function. Initial complaints such as sense loss, numbness, double vision and walking difficulty are often weakness, however as the disease progresses, severe complications are observed from blindness to the loss of consciousness $[3,4]$.

The results of an international study published in 1996 indicated that the outcome can be categorized into four categories. 1. Relapse and Remissions Multiple sclerosis (RRMS) (Attacks and recovery MS), 2. Primer progressive multiple sclerosis (PPMS), 3. Secondary progressive multiple sclerosis (SPMS), 4. Relapsing progressive multiple sclerosis (RPMS).

In spite of intensive research, both the etiology and the pathogenesis of MS are not completely resolved. One of the important and most commonly studies have been conducted on one carbon metabolism pathway (OCMP) since it has major impacts on the development of MS. Homocysteine (Hcy), folic acid (FA) and vitamin B (Vit B) have key components of OCMP. $\mathrm{Hcy}$ is a sulphurous amino acid, not involved in protein 
structure. It is an essential amino acid and intakes from foods and also, synthesized from endogenous proteins. It is a methylated group of methionine and is metabolized by converting it back to methionine via remission, or by transsulphurisation, converting it into cysteine, methyl malonic and 2-methylcitric acid [5]. Elevated plasma Hcy levels cause hyperhomocysteinemia and consequently homocysteineuria. It is shown that increased plasma Hcy levels are a significant risk factor for diseases [6]. Increased Hcy levels can be taken at normal levels with FA intake. Therefore, investigating the cause of the increase in plasma Hcy which is a risk factor for many diseases and withdrawal of normal levels from food is important for health [7]. The etiology of hyperhomocysteinemia is considered to be multifactorial (genetic, nutritional, and lifestyle factors), not related to only FA intake, and there is an ongoing debate regarding the relative contribution of each factor. It is proposed that high
Hcy levels are due to genetic polymorphism on enzymes which have important roles on OCMP. Causal mechanisms of MS development including the identification of the folatemediated one carbon pathway that is directly involved in MS development.have yet to be established,

Figure 1 demonstrates genetic polymorphisms which have major roles on OCMP. This pathway is named for one carbon folic acid or one carbon metabolism pathway since a carbon unit from serine or glycine is transferred to tetrahydrofolate (THF) to form methylene tetrahydrofolate (MTHF). Folateactivated one carbon is required for the de novo synthesis of purines and thymidylate and for the remethylation of Hcy to methionine. Methionine is used for protein synthesis or transforming S-adenosine methionine (SAM) which is required for polyamine synthesis and for numerous methylation reactions.
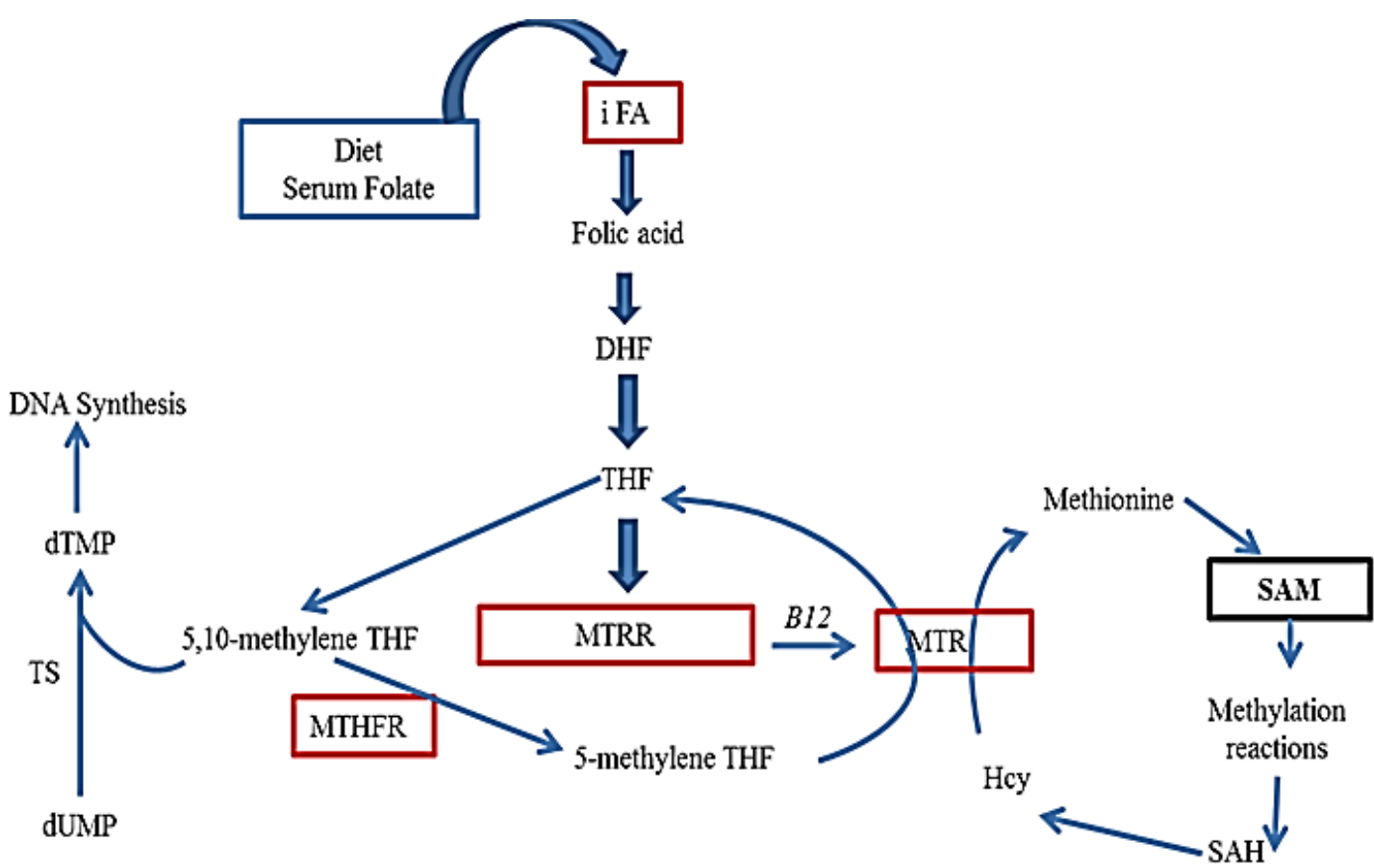

Figure 1 Production of homocysteine as part of the amino acid and purine biosynthesis pathway (DHF: Dihydrofolate, THF: Tetrahydrofolate, MTHFR: Methylene Tetrahydrofolate-Reductase, TS: Thymidylate Synthase, MTR: Methionine Synthase, MTRR: Methionine Synthase Reductase, SAM: S-Adenosine Methionine, SAH: S-Adenosine Homocysteine).

Methylene tetrahydrofolate-reductase (MTHFR) is an enzyme and have impact on the levels of Hcy and metabolism of methionine. It catalyzes reduction of 5, 10-methylene THF (5, 10-MTHF) to 5-methyl THF (5-THF). 5- THF acts as a methyl donor during synthesis of methionine from Hcy. In case of genetic polymorphism, MTHFR enzyme activity decreases and failure to synthesize methionine from Hcy thus, leads high levels of Hcy [8].

\section{The impacts of Hcy, FA and VitB12}

Increase in Hcy levels due to FA and VitB12 deficiency causes the decrease in cellular S-adenosine methionine (SAM) level and consequently the inhibition of SAM dependent methylation reactions in the CNS. Therefore, this pathway is important for the risk of neurogenerative diseases such as MS. Disruptions or impairments in folate metabolism are associated to several diseases. Impairments in the folatedependent one-carbon network can arise from a primary folate deficiency, secondary VitB12 nutrient deficiencies and genetic variations influence cellular folate accumulation and/or utilization.

So far, it has been known very well that high levels of Hcy and FA are associated to risk of many diseases not only impact on the development of MS. In a case-control study, it was reported that increased levels of FA reduced the risk of colorectal cancer by $50 \%$ [9]. There are numerous published 
studies which report higher levels of Hcy and lower levels of folate were risk factors for cardiovascular diseases $[9,10]$. Diabetes, renal insufficiency, different types of cancers, ovarian failure is associated with hyperhomocysteinemia [11-13]. However, the most important disease group, which is associated with FA deficiency and hyperhomocysteinemia, is neurological and psychiatric diseases. In recent years, there have been a number of publications that FA is associated with diseases such as Parkinson's, MS, Alzheimer, stroke, anxiety disorders, depression, schizophrenia, bipolar disorder, congenital neural tube defects [14-16]. High levels of Hcy are toxic to neural cells therefore $\mathrm{Hcy}$ contributes to the pathogenesis of neurodegenerative disorders. Furthermore, psychiatric disorders via neuronal degeneration due to Hcy take place. As mentioned Figure 1 (above), inhibition of methylation causes to the decreased methylation of phospholipids in neuronal membranes, thus leads the impaired stability of neuronal cell membranes. It has been discussed and proposed hypothesis that impaired methylation of Myelin Basic Protein (MBP), the major component of the myelin sheath, triggers the risk of MS. It was reported that these effects contribute to the pathogenesis of various psychiatric and neurological disorders $[14,15,17]$ and also many reports showed that high levels of Hcy were observed in MS [18-24].

\section{Genetic susceptibility and the risk of MS}

Investigations on genetic polymorphisms provide data for the role of individual susceptibility to the development of MS. It is essential to solve its underlying mechanism. There are numerous reasons causing the development of MS especially, individual susceptibility should not be neglected. We have focused on three gene polymorphisms namely Methylene tetrahydrofolate reductase (MTHFR) C677T, A1298C and Methionine synthase (MTR) G66A since they are key enzymes on OCMP. There are two reasons to show the association with the MTHFR C677T polymorphism to disease. First, the disease might influence the levels of Hcy and there might be effect modification by the MTHFR gene polymorphism. Second, the genotype might be associated with disease risk, possibly mediated by altered metabolism of folates and Hcy $[6,25]$. The MTHFR gene consists of 11 exons and has identified 14 mutations. C677T and $\mathrm{A} 1298 \mathrm{C}$ point mutations are the most common among them and result in loss of enzyme activity. In C677T polymorphism, cytosine (C) at the position 4th exon 677 transits to thymine $(T)$. As a result, valine amino acid is substituted for the 226th amino acid domain of the enzyme structure. This polymorphism of the enzyme leads to loss of activity. The loss of activity of enzymes are related to the development of MS. The prevalence of C677T gene polymorphism differs from among ethnic groups such as $1 \%$ or less is in sub-Saharan African and US blacks and $25 \%$ or more is for Italians, US Hispanics [26]. Table 1 demonstrates the distribution of these gen polymorphisms on different populations. Other commonly studied gene polymorphism is A1298C polymorphism. The nucleotide at 1298th nucleotide in the 7th exon changes from A (Adenine) to C (Cytosine). This point mutation causes the change of glutamine to alanine in
MTHFR protein. In this mutation, MTHFR activity is reduced as it is in other mutation types [27]. MTR is the enzyme that synthesizes methionine from Hcy by transferring methyl and consists of 1265 amino acids. MTR gene locates at chromosome $1 q 43$ with 33 exons. One of the most studied polymorphisms in the MTR gene is $A 2756 G$ and $A>G$ transition at 27. Exon 2756 leads the amino acid substitution of glycine to aspartic acid. This polymorphism decreases enzyme activity as the VitB12 cofactor regulates its reactivation and role in methylation [28,29]. Methionine synthase reductase (MTRR) plays a critical role in maintaining VitB12 in an active form. It has pivotal role on total plasma Hcy level. Elevated Hcy contributes to the CNS dysfunction, neurodegenerative, and cerebrovascular disease [30,31]. In the A66G gene polymorphism, isoleucine residues have been reported to be the remnants of methionine and has been reported to increase plasma homocysteine levels [28,32].

There are conflicting results in the literature about the association between C677T, A1298C MTHFR, MTR A2756G and A66G MTRR gene polymorphisms and the risk of the development of MS. Çevik et al. study MTHFR C677T gene polymorphism in Turkish population included $130 \mathrm{MS}$ patients and 150 group-matched controls. Results show that the genotype and allele frequencies of the gene polymorphism are statistically significant different between MS patients and controls. Furthermore, T allele of C677T polymorphism was associated with MS susceptibility in Turkish population [33]. Fekih Mrissa et al. conducted a case-control (case $n=39$ and controls $n=104$ ) study in Tunisia population. They found a statistically significant difference in the frequency of MTHFR A1298C between controls and MS patients. Subjects with CC genotype was about 4 times higher the risk of MS. On the other hand, no significant difference was found in the MTHFR C677T gene polymorphism between controls and MS patients [34]. In UK Caucasian population, similar study was performed with larger sample size ( $n=104$ patients) and it was found that the frequencies of MTHFR A1298C mutant genotypes were higher in MS patients compared to controls however it could not reach the significance. They suggested that it needed to be performed further studies with larger sample size to confirm their study results [35]. The association between MTHFR C677T and $A 1298 C$ missense variants and the risk of MS was investigated in a Southern Iranian population (controls $n=231$ and patients $n=180$ ). Compared with controls, a strong association between two gene variants and the risk of MS was found. Subjects carrying 677T allele (CT and TT genotypes) had higher MS risk than subjects carrying CC genotype (2.9 times and 6.23, respectively). The variant 1298AC genotype also increased the risk for MS and 2.14 times higher MS risk was observed subjects carrying mutant genotypes [36]. Two polymorphisms MTRR A66G and MTHFR A1298C were investigated in an Australian case-control population (140 controls and 140 patients) study. No significant allelic frequency difference was observed between cases and controls [37]. The genotype frequencies of the missense variant MTHFR 1298A > C investigated study in Germany were significantly different between patients (1298AA: 1298:AC and 1298 CC and 0.34: 0.55: 0.11) and controls (0.52: 0.36: 0.12). 
These results suggest that homozygosity for the A allele of MTHFR 1298A > C may be protective against the incidence of MS [38]. As result in MTHFR C677T polymorphism C allele is protective, CT and TT genotypes have increased MS risk. For MTHFR A1298C polymorphism A allele is protective, AC and CC genotypes have increased the risk of MS. However, results do not support a major role for either functional gene mutation in MS susceptibility. But for MTR A2756G and MTRR A66G polymorphisms, there are not enough studies. Hence, further studies are need to be conducted (Table 1) [39-58].

Table 1 The prevalence of MTHFR C 677T, A1298C, MTRR A66G and MTR A2756G in different populations.

\begin{tabular}{|c|c|c|c|c|c|c|c|c|c|c|c|c|}
\hline \multirow[t]{3}{*}{ Population } & \multicolumn{6}{|c|}{ MTHFR gene polymorphism } & \multicolumn{3}{|c|}{$\begin{array}{l}\text { MTRR A66G } \\
\text { gene polymorphism } \\
(\%)\end{array}$} & \multicolumn{3}{|c|}{$\begin{array}{l}\text { MTR A2756G } \\
\text { gene polymorphism } \\
(\%)\end{array}$} \\
\hline & \multicolumn{3}{|c|}{ C 677T (\%) } & \multicolumn{3}{|c|}{ A1298C (\%) } & \multirow[b]{2}{*}{ AA } & \multirow[b]{2}{*}{ GA } & \multirow[b]{2}{*}{ GG } & \multirow[b]{2}{*}{ AA } & \multirow[b]{2}{*}{ AG } & \multirow[b]{2}{*}{ GG } \\
\hline & $\mathrm{CC}$ & CT & TT & AA & $A C$ & $\mathrm{CC}$ & & & & & & \\
\hline $\begin{array}{l}\text { Turkey } \\
\text { Sivas }\end{array}$ & 54 & 42 & 4 & 46 & 46 & 8 & & & & & & \\
\hline $\begin{array}{l}\text { Turkey [39] } \\
\text { Ankara }\end{array}$ & 34 & 54 & 12 & 42 & 46 & 12 & & & & & & \\
\hline Iran [36] & 65 & 29 & 6 & 42 & 46 & 12 & & & & & & \\
\hline China [40] & 32 & 45 & 23 & 77 & 19 & 4 & 67 & 26 & 7 & & & \\
\hline Ukraine [41] & 50 & 43 & 7 & & & & & & & & & \\
\hline Turkey [42] & & & & 32 & 67 & 1 & 10 & 86 & 4 & 57 & 38 & 5 \\
\hline UK [43] & 46 & 45 & 9 & & & & & & & & & \\
\hline USA [44] & 22 & 49 & 29 & & & & 32 & 62 & 6 & & & \\
\hline USA [45] & & & & & & & 22 & 48 & 30 & 71 & 26 & 3 \\
\hline Turkey [31] & & & & & & & 9 & 78 & 13 & 64 & 35 & 1 \\
\hline China [13] & 34 & 51 & 15 & 71 & 25 & 4 & 51 & 40 & 9 & & & \\
\hline China [46] & 25 & 50 & 25 & 70 & 27 & 3 & 32 & 50 & 17 & 82 & 17 & 1 \\
\hline Lebanon [47] & 49 & 40 & 11 & & & & & & & & & \\
\hline Tunusia [34] & 52 & 40 & 8 & 93 & 7 & 0 & & & & & & \\
\hline Australia [35] & 46 & 44 & 11 & & & & & & & & & \\
\hline Indonesia [48] & 82 & 14 & 4 & & & & & & & & & \\
\hline Bosnia 49 & 44 & 45 & 11 & & & & & & & & & \\
\hline Pakistan [50] & 70 & 29 & 1 & 23 & 73 & 4 & & & & & & \\
\hline Australia [37] & & & & 48 & 37 & 15 & 38 & 52 & 10 & & & \\
\hline $\begin{array}{l}\text { China uyghur } \\
\text { [51] }\end{array}$ & 35 & 53 & 12 & 62 & 32 & 6 & & & & & & \\
\hline Germany [38] & & & & 52 & 36 & 12 & & & & & & \\
\hline Turkey [52] & 71 & 27 & 2 & & & & & & & & & \\
\hline Jordan [53] & 49 & 45 & 6 & 39 & 50 & 11 & 40 & 45 & 15 & & & \\
\hline Brazil [54] & 49 & 42 & 9 & 68 & 26 & 6 & 28 & 54 & 18 & 77 & 20 & 3 \\
\hline Brazil [55] & 52 & 37 & 11 & 44 & 50 & 11 & & & & 64 & 35 & 1 \\
\hline Syria [56] & 46 & 46 & 8 & 52 & 38 & 10 & 34 & 46 & 20 & & & \\
\hline Indian [57] & & & & & & & 46 & 54 & 0 & 54 & 42 & 4 \\
\hline Taiwan [58] & 58 & 35 & 7 & & & & & & & 59 & 38 & 3 \\
\hline
\end{tabular}




\section{Conclusion}

In conclusion, genetic susceptibility should not be neglected to the development and treatment of MS. Although there are many conflictive results, when compile the data on the relation between genetic polymorphisms and the development of MS, genetic factors have important impact.. Meta-analyses and studies with larger sample size needs to be conducted and enzyme activities should be detected and correlations with genetic polymorphisms needs to be made to show the underlying mechanism of MS.

\section{Conflict of Interest}

There is no conflict of interest.

\section{References}

1. Cevik I (2013) Multipl Sklerozda Tanı ve Tedavi kılavuzu. Istanbul: Galenos Yayınevi 5-6.

2. Mirza M (2002) Multipl Sklerozun Etiyolojisi ve epidemiyolojisi. Erciyes Tip Dergisi. Erciyes Med J 24: 40-47.

3. Yılmaz NC (2006) Multiple Skleroz Ve Otoimmunite. Uzmanlık tezi, T.C.Saglık Bakanlıgı Haydarpasa Numune Egitim Ve Arastirma Hastanesi, Istanbul 1-7.

4. Freeman H (2008) Basic information About MS. MS Society. pp: 11-12.

5. Koc Y (2007) Homosistein Metabolizmasında Rol Oynayabilecek Gen Degisimlerinin Incelenmesi. Yüksek Lisans Tezi, Ankara Universitesi Biyoteknoloji Enstitusu, Ankara 12-13.

6. Ueland PM, Hustad S, Schneede J, Refsum H, Vollset SE (2001) Biological and clinical implications of the MTHFR C677T polymorphism. Trends Pharmacol Sci 22: 195-201.

7. Keser N, Pazarbaşı A, Ozpak L (2014) Metilentetrahidrofolat Redüktaz Aktivitesi ve Folat Metabolizması. Archives Medical Review Journal 23: 237-256.

8. Yasar A, Gunduz K, Onur E, Calkan M (2012) Serum homocysteine, vitamin B12, folic acid levels and methylenetetrahydrofolate reductase (MTHFR) gene polymorphism in vitiligo. Dis Markers 33: 85-89.

9. Mattson MP, Kruman II, Duan W (2002) Folic acid and homocysteine in age- related disease. Ageing Res Rev 1: 95-111.

10. Temel I, Ozerol E (2002) Homosistein metabolizma bozukluklar ve vasküler hastalıklarla ilişkisi. Inonu Universitesi Tıp Fakultesi Dergisi 9: 149-157

11. Ulucan K, Karahan M, Saglam E (2013) Folik asit metabolizmasının biyokimyasal ve moleküler açıdan Parkinson, Alzheimer, bipolar ve sizofrenik bozukluklara etkisi. Anadolu Psikiyatri Derg 14: 378-382.

12. Mattson MP, Shea TB (2003) Folate and homocysteine metabolism in neural plasticity and neurodegenerative disorders. Trends Neurosci 26: 3.

13. Hou N, Chen S, Chen F, Jiang M, Zhang J, et al. (2016) Association between premature ovarian failure, polymorphisms in MTHFR and MTRR genes and serum homocysteine concentration. Reprod Biomed Online.
14. Rajagopalan P, Jahanshad N, Stein JL, Hua X, Madsen SK, et al. (2012) Commonfolate gene variant, MTHFR C677T, is associated with brain structure in two independent cohorts of people with mild cognitive impairment. Neuroimage Clin 1: 179-187.

15. Reynolds E (2006) Vitamin B12, folic acid, and the nervous system. Lancet Neurol 5: 949-960

16. Cosar A, Ipcioglu OM, Ozcan O, Gul-tepe M (2014) Folate and homocysteine metabolisms and their roles in the biochemical basis of neuropsychiatry. Turk J Med Sci 44: 1-9.

17. Sen S, Durat G, Atasoy I (2009) Vitamin B 12 ve Folik Asit Eksikliginin Psikiyatrik ve Norolojik Bozukluklarla Iliskisi. Turk Klinik Biyokimya Derg 7: 31-36.

18. Kocer B, Engur S, Aka F, Yılmaz M (2009) Serum vitamin B12, folate, and homocysteine levels and their association with clinical and electrophysiological parameters in multiple sclerosis. J Clin Neurosci 16: 399-403.

19. Besler HT, Comoglu S (2003) Lipoprotein oxidation, plasma total antioxidant capacity and homocys-teine level in patients with multiple sclerosis. Nutr Neurosci 6: 189-196.

20. Akpınar Z, Kurba S (2013) Serum nitric oxide, homocystein, asymmetric dimethylarginine levels in patients with multiple Sclerosis. Selcuk Tıp Derg 29: 168-171.

21. Masoud SA, Neurosurjery EF (2009) Relationship between homocystein blood level and multiple sclerosis. Int J Med Med Sc 1: 230-232.

22. Ramsaransing GSM, Fokkema MR, Teelken A, Arutjunyan AV, Koch $M$, et al. (2006) Plasma homocysteine levels in multiple sclerosis. J Neurol Neurosurg Psychiatry 77: 189-192

23. Wisniewska A, Beltowski J, Psujek HB, Wojcicka G, Rejdak K (2016) Processes of plasma protein $\mathrm{N}$-homocysteinylation in multiple sclerosis. Int J Neurosci 1-7.

24. Teunissen CE, Killestein J, Kragt JJ, Polman CH, Dijkstra CD, et al. (2008) Serum homocysteine levels in relation to clinical progression in multiple sclerosis. J Neurol Neurosurg Psychiatry 79: 1349-1353.

25. Mattson MP (2002) Folic acid and homocysteine in age-related disease. Ageing Res Rev pp: 95-111.

26. Liew SC, Gupta ED (2015) Methylenetetrahydrofolate reductase (MTHFR) C677T polymorphism: Epidemiology, metabolism and the associated diseases. Eur J Med Genet 58: 1-10.

27. Koçak N, Ozen F, Yıldırım MJ, Ozdemir O (2009) Metilentetra hidrofolat Redüktaz (MTHFR) C677T ve A1298C Gen Polimorfizmleri. Inonu Universitesi Tip Fakültesi Dergis 16: 157-161.

28. Ouyang S, Yuanyuan L, Zhuo L, Huibo C, Jianxin W (2013) Association between MTR A2756G and MTRR A66G polymorphisms and maternal risk for neural tube defects: $A$ meta-analysis. Gene 515: 308-312.

29. Drennan CL, Matthews RG, Ludwig ML (1994) Cobalamindependent methionine synthase: the structure of a methylcobalamin-binding fragment and implications for other B12-dependent enzymes. Curr Opin Struct Biol 4: 919-929.

30. Olteanu H, Banerjee $R$ (2001) Human methionine synthase reductase, a soluble $\mathrm{P}-450$ reductaselike dual flavoprotein, is sufficient for NADPH-dependent methionine synthase activation. J Biol Chem 276: 35558-35563.

31. Kucukaslan AS, Altintas R, Cetintas VB, Tetik A, Ulukus M, et al. (2011) Erkek infertilitesinde metiyonin sentaz A2756G ve 
metiyonin sentaz redüktaz A66G gen polimorfizmlerinin etkisi. Turk Uroloji Dergisi 37: 38-42.

32. Gaughan DJ, Kluijtmans LAJ, Barbaux S, McMaster D, Young IS, et al. (2001) The methionine synthase reductase (MTRR) A66G polymorphism is a novel genetic determinant of plasma homocysteine concentrations. Atherosclerosis 157: 451-456.

33. Cevik B, Serbulent Y, Karakus N, Ates O (2014) Association of methylenetetra hydrofolate reductase gene C677T polymorphism with multiple sclerosis in Turkish patients. J Investig Med 62: 980-984.

34. Fekih Mrissa N (2013) Association of methylenetetra hydrofolate reductase $A 1298 C$ polymorphism but not of C677T with multiple sclerosis in Tunisian patients. Clin Neurol Neurosurg 115: 1657-1660.

35. Lotti T, Martin V, Gasparini C, Ovcaric M, Curtain R, et al. (2006) Genetic investigation of methylenetetrahydrofolate reductase (MTHFR) and catechol-O-methyl transferase (COMT) in multiple sclerosis. Brain Res Bull 69: 327-331.

36. Naghibalhossain F, Ehyakonandeh $H$, Nikseresht A, Kamali E (2015) Association Between MTHFR Genetic Variants and Multiple Sclerosis in a Southern Iranian Population. Int J Mol Cell Med Spring 4: 2.

37. Szvetko AL, Fowdar J, Nelson J, Colson N, Tajouri L, et al. (2007) No association between MTHFR A1298C and MTRR A66G polymorphisms, and MS in an Australian cohort. J Neurol Sci 252: 49-52.

38. Klotz L, Farkas M, Bain N, Keskitalo S, Semmler A, et al. (2010) The variant methylenetetrahydrofolate reductase c.1298A > C (p. E429A) is associated with multiple sclerosis in a German case-control study. Neurosci Lett 468: 183-185.

39. Uguz N, Erden G, Gungor O, Bal C, Yıldırımkaya M (2012) MTHFR geninde C677T ve/veya A1298C polimorfizmi tespit edilen bireylerde bu polimorfizm sıklıklarının incelenmesi. J Clin Exp Invest 3: 472-476.

40. B Yang, Y Liu (2013) Geographical distribution of MTHFR C677T, A1298C and MTRR A66G gene polymorphisms in china: Findings from 15357 adults of Han Nationality. PLoS One 8: e57917.

41. Tatarskyy P, Kucherenko A, Livshits L (2010) Allelic polymorphism of F2, F5 and MTHFR genes in population of Ukraine. Tsitol Genet 3.

42. Aşlar D, Taştan H (2014) Prevalence of MTHFR, MTR and MTRR Gene Polymorphisms in Turkish Patients with Nonsyndromic Cleft Lip and Palate Research Article, Gene Ther Mol Biol 16: 115-129.

43. Zandra RH, Hannah C (1999) The C677T MTHFR gene mutation is not predictive of risk for recurrent fetal loss. Br J Haematol 105: 98-101.

44. Zhi X, Yang B, Fan S, Li Y, He M, et al. (2016) Additive interaction of MTHFR C677T and MTRR A66G polymorphisms with being overweight/obesity on the risk of type 2 diabetes. Int J Environ Res Public Health 13: 1243.

45. Zhang Z, Shi Q, Liu Z, Sturgis ER, Spitz MR, et al. (2005) Polymorphisms of methionine synthase and methionine synthase reductase and Risk of Squamous Cell Carcinoma of the Head and Neck: A case-control analysis. Cancer Epidemiol Biomarkers Prev 14: 1188-1193.

46. Li WX, Lv WW, Dai SX, Pan ML, Huang JF (2015) Joint associations of folate, homocysteine and MTHFR, MTR and MTRR gene polymorphisms with dyslipidemia in a Chinese hypertensive population: A cross-sectional study. Lipids Health Dis 14: 101.

47. Almawi WY (2004) Differences in the Frequency of the C677T Mutation in the Methylenetetrahydrofolate Reductase (MTHFR) Gene Among the Lebanese Population. Am J Hematol 76:85-87.

48. Pramukarso DT (2015) Association between methylenetetrahydrofolate reductase (MTHFR) polymorphism and carotid intima medial thickness progression in post ischaemic stroke patient. Ann Transl Med 3: 324.

49. Amela K, Rifet T, Zoran J, Jasminka MM (2013) The frequency of C677T Methylenetetrahydrofolate Reductase (MTHFR) polymorphism in Southern East Bosnian Population Amela et al., J Biomet Biostat 4: 4.

50. Micheal S, Qamar R, Akhtar F, Khan MI, Khan W, et al. (2009) MTHFR gene C677T and A1298C polymorphisms and homocysteine levels in primary open angle and primary closed angle glaucoma. Molecular Vision 15: 2268-2227.

51. Li Z, YadavU, Mahemuti A, Tang BP, Upur H (2015) Association of MTHFR genetic polymorphisms with venous thromboembolism in Uyghur population in Xinjiang, China. Int J Clin Exp Med 8: 17703-1771.

52. Kalkan G (2013) Methylenetetra-hydrofolate reductase C677T mutation in patients with alopecia areata in Turkish population Gene 530: 109-112.

53. Mfady DS (2014) Associations of variants in MTHFR and MTRR genes with male infertility in the Jordanian population Gene. 536: 40-44.

54. Lima CSP (2008) Polymorphisms of methylenetetra hydrofolate reductase (MTHFR), methionine synthase (MTR), methionine synthasereductase (MTRR), and thymidylate synthase (TYMS) in multiple myeloma risk. Leukemia Research 32: 401-405.

55. Barbosa (2012) Interaction of MTHFRC677T and A1298C, and MTR A2756G gene polymorphisms in breast cancer risk in a population in Northeast Brazil. Anticancer Research 32: 4805-4812.

56. Lajin B (2012) Association between MTHFR C677T and A1298C, and MTRR A66G polymorphisms and susceptibility to schizophrenia in a Syrian study cohort. Asian J Psychiatr 5: 144-149.

57. Murthy J (2015) Genetic variant in MTRR A66G, but not MTR A2756G, is associated with risk of non-syndromic cleft lip and palate in Indian population. J Oral Maxillofac Surg Med Pathol 7: 782-785.

58. Fong CS (2011) Association of MTHFR, MTR, and MTRR polymorphisms with Parkinson's disease among ethnic Chinese in Taiwan. Clinica Chimica Acta 412: 332-338. 